Çukurova Üniversitesi Mühendislik Mimarlık Fakültesi Dergisi, 30(2), ss. 217-226, Aralık 2015

\title{
Gaziantep-Şehit Kamil-Karpuzkaya Bölgesi Kalker İşletmesinin Patlatma Parametrelerinin İncelenmesi ve Patlatma Sonrası Parça Boyut Dağılımının Belirlenmesi
}

\author{
Ahmet Mahmut KILIÇ* \\ ${ }^{1}$ Çukurova Üniversitesi, Mühendislik Mimarlık Fakültesi, Maden Mühendisliği Bölümü, Adana \\ Geliş tarihi: 09.11.2015 \\ Kabul tarihi:25.12.2015
}

\section{Özet}

Taş ocağı işletmelerinde patlatma sonrası oluşan yığının tane boyutu maliyet açısından çok önemlidir. Tasarım parametrelerinin seçiminde istenilen parça boyutunu sağlayacak en uygun tasarım yapılmalıdır. $\mathrm{Bu}$ çalı̧̧mada Gaziantep-Şehitkamil-Karpuzkaya Bölgesinde bulunan taş ocağının patlatma parametreleri incelenmiştir. Patlatma öncesi ve sonrası görüntüler alınarak WipJoint ve WipFrag yazılımları yardımıyla parça boyut analizi yapılmıştır. Patlatma tasarım parametrelerinin istenilen parça boyutunu sağlayıp sağlamadığı incelenmiştir.

Anahtar Kelimeler: Patlatma, Wip frag, Parça-boyut, Maliyet, Kireçtaşı

\section{Investigation of Blasting Parameters of Gaziantep-Şehit Kamil-Karpuzkaya Area Limestone Quarry and Determination of Post-Blast Particle Size Distribution}

\begin{abstract}
Post-blast particle size distribution is very important in terms of cost in limestone quarry. In the selection of design parameters to provide the desired particle size should be the most appropriate design. This study examined of blasting parameters the limestone quarry in the Gaziantep-Şehitkamil-Karpuzkaya. Images taken post blasting and pre-blasting particle size analysis was conducted with the via of WipJoint and WipFrag software. Blasting design parameters for compliance with the required particle size was investigated.
\end{abstract}

Keywords: Blasting, Wipfrag, Particle-size, Cost, Limestone

\footnotetext{
* Yazışmaların yapılacağı yazar: Ahmet Mahmut KILIÇ, Mühendislik Mimarlık Fakültesi, Maden Mühendisliği Bölümü, Adana, kilicm@cu.edu.tr
} 


\section{GíRiș}

Ülkemizde ve tüm dünyada yapı ve madencilik sektörlerinde büyük ölçüde ilerleme gözlenmektedir. Bu ilerlemelerle birlikte her iki sektör içinde önemli önceliğe sahip olan delmepatlatma işleri de büyük önem kazanmıştır. Delme ve patlatma işlemleri işletmeler için büyük bir maliyet oluşturmaktadır. Ayrıca bu maliyetler patlatma sonrası da devam etmektedir. Patlatma sonrasi maliyete etki eden parametreler ise nakliyat, kırma ve eleme işlemleridir. Bundan dolayı uygulanan patlatma yöntemi çok iyi bir şekilde dizayn edilmelidir. Patlatma sonrası oluşan yığında patar (iri blok) oluşmamasına dikkat edilerek istenilen boyutlara uygun numune elde etme yoluna gidilmelidir. Bunu önlemekte patlatma tasarım parametrelerinin iyi belirlenmesi ve böylelikle de istenilen parça boyutuna uygun numune elde edilmesinin sağlanması ile mümkündür.

Taş ocağında maliyet oluşturan önemli unsur olan patar (iri blok) oluşumudur. $\mathrm{Bu}$ nedenle patar oluşumuna engel olmak gerekmektedir. Eğer patlatma sonucu elde edilen ürün içerisinde patar (iri parça) oluşumu yok ise özel bir işleme gerek kalmadan ve nakliye giderini arttırmadan elde edilen ürün, direk krrma-eleme tesisine gönderilecektir.

Kırma-eleme tesisine dökülen malzeme ilk önce çeneli (primer kırıcı) kırıcıya gönderilmektedir. çeneli kırıcıda kaba bir kırma işleminden geçirilip (yaklaşık 1/6 oranında kırılan malzeme) malzeme bant konveyörler vasitasıyla sekonder (darbeli kırıcı) kırıcıya gönderilmektedir. İkinci kırma ünitesine gelen malzeme burada kırılmadan önce ızgaralı elekten geçirilmekte ve elek üstü malzeme bant konveyörler vasitasıyla tekrar kırılmak üzere çeneli kırıcıya gönderilmektedir. Elek altı malzeme ise darbeli kırıcılara gelerek burada daha küçük boyutlara indirilmektedir. Darbeli kırma işleminden geçen malzeme bant konveyör vasıtasıyla titreşimli eleklere gönderilmektedir. Titreşimli elek üzerinde kalan malzeme tekrar kırılmak üzere bant konveyörler vasitasiyla Darbeli kırıcıya, elek altı malzeme ise elek sisteminden geçirilerek tane boylarına göre sınıflandırılmaktadır. Malzeme 1 grup; 0-3 mm, 2 grup; $3-7 \mathrm{~mm} 3$ grup; $7-15 \mathrm{~mm}$ ve 4 grup; $15-25$ $\mathrm{mm}$ olacaktır. Bu işlemleri çok fazla geri dönüş olmadan ilerlemesi ancak istenilen parça boyutuna uygun patlatılmış numune elde etmekle mümkün olabilecektir. $\mathrm{Bu}$ bağlamda patlatma sonucu istenilen parça boyutunun elde edilmesi son derece önemlidir.

$\mathrm{Bu}$ çalışmada Gaziantep İli Şehitkamil İlçesi Karpuzkaya Köyü mevkiinde bulunan kalker işletmesinin patlatma parametreleri incelenmiş ve patlatma öncesi ve sonrası alınan ölçekli fotoğraflar ile parça-boyut analizi yapılmıştır. $\mathrm{Bu}$ analiz sonucunda patlatma parametrelerinin ekonomik olup olamadığı incelenmiştir.

\section{2. ÇALIŞMA ALANI HAKKINDA GENEL BÍLGILER}

Gaziantep İli, Şehitkamil İlçesi Karpuzkaya Köyü dahilinde 1/25.000 ölçekli jeolojik haritada N38-d2 paftasında yer alan er:3092577 erişim no'lu, 20061225 ruhsat no'lu, II. grup (Doğaltaş-Mermer) işletme ruhsatlı 87,4 hektar'lık kalker ocağı çalışma alanı olarak seçilmiştir.

\subsection{Coğrafi Konum}

Çalışma sahası, Gaziantep il merkezi ve Şehitkamil ilçe merkezine kuş uçuşu yaklaşık $23 \mathrm{~km}$, Gaziantep-Kahramanmaraş eski karayoluna yaklaşık 600 metre ve Gaziantep-Adana Otobanına ise yaklaşık 200 metre uzaklıkta yer almaktadır. Çalışma sahası uydu görüntüsü Şekil 1'de ve Şekil 2'de sahaya ait genel ocak görüntüsü görünmektedir.

\subsection{Bölgesel Jeoloji}

Çalışma alanının genel jeolojisi MTA tarafından yapılmıştır olup Gaziantep İli jeolojik özellikleri çalışmasından yararlanılmıştır. Çalışma sahası içeresinde gözlenen birimler sırasıyla Eosen yaşlı Hoya formasyonu ve Plio-kuaterner yaşlı birim yer almaktadır. Şekil 3'de MTA tarafından yapılmış jeolojik harita görülmektedir. 


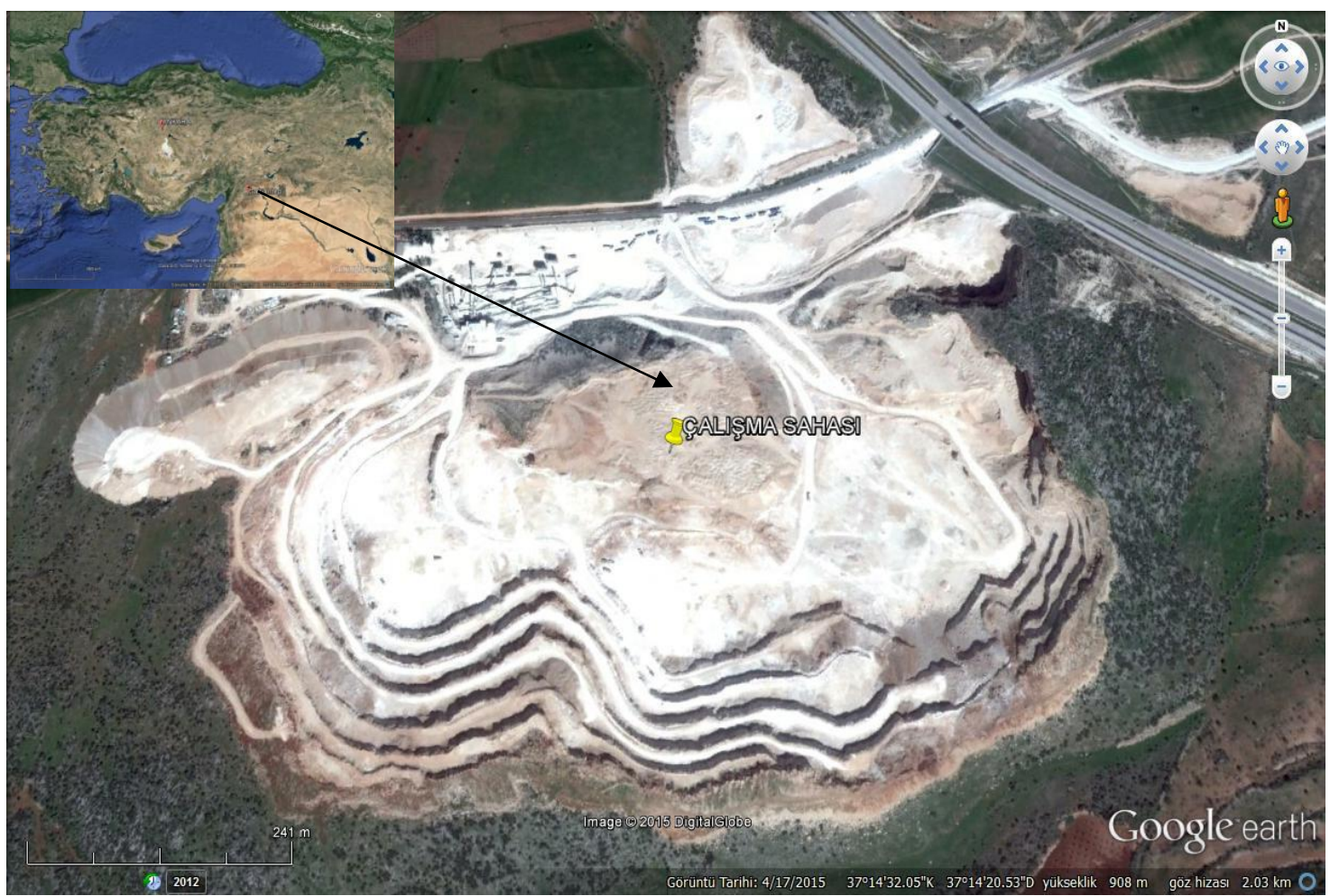

Şekil 1. Çalışma sahası uydu görüntüsü

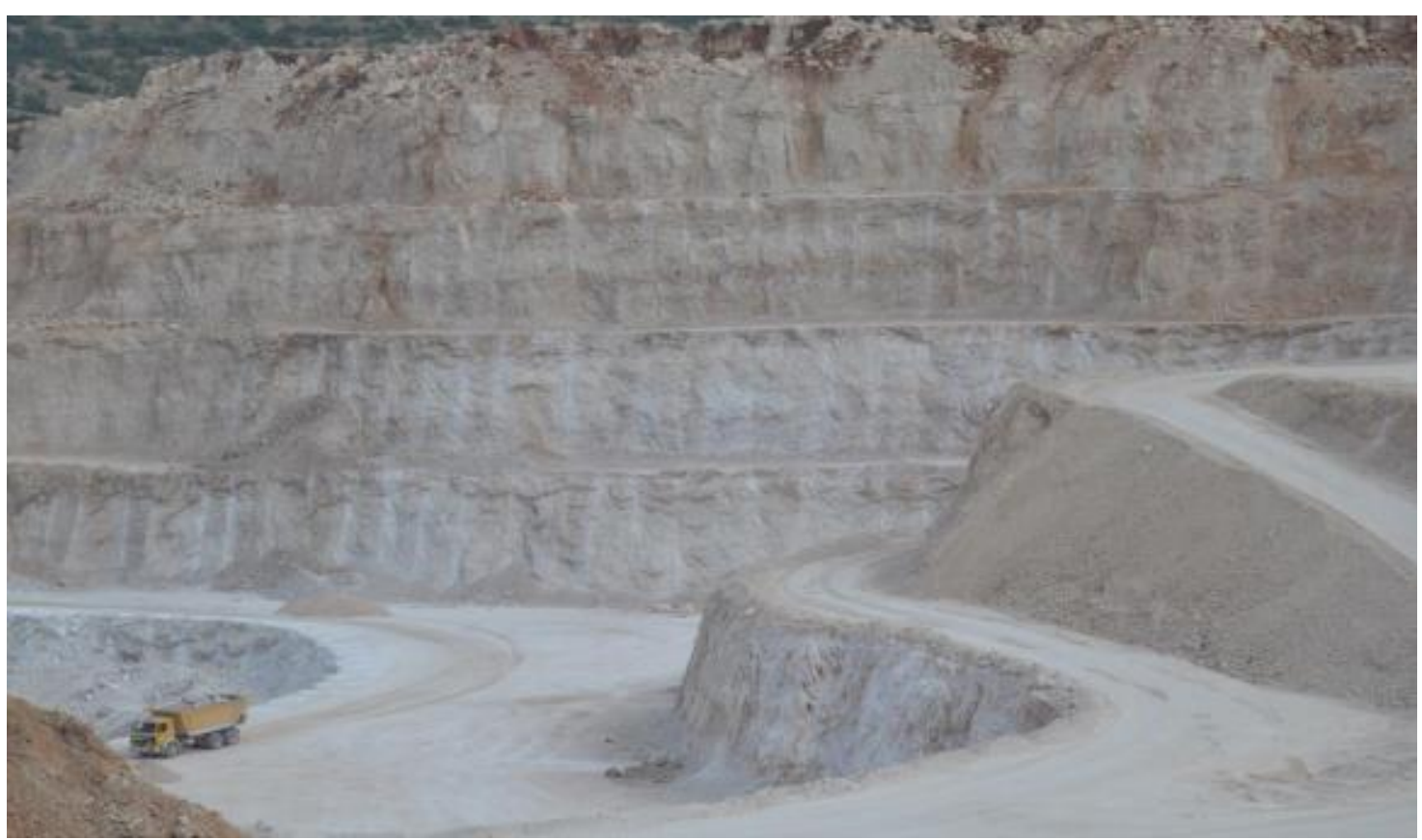

Şekil 2. Sahaya ait genel görüntü 
Gaziantep-Şehit Kamil-Karpuzkaya Bölgesi Kalker Işsletmesinin Patlatma Parametrelerinin İncelenmesi ve Patlatma Sonrası Parça Boyut Dağılımının Belirlenmesi

Karbonatlardan oluşan birim Sungurlu (1974) [1] tarafindan adlandırılmıştır. Birim Kırma-eleme tesisimizin bulunduğu alanda yüzlek göstermektedir. Formasyonun egemen kaya türü kireçtaşıdır. Altta çakıllı kireçtaşı ile başlar. Gri, bej, yer yer kırmızı renkli, kalın-çok kalın tabakalı olan kireçtaşları, üste doğru kireçtaşına geçer. $\mathrm{Bu}$ kireçtaşları krem-kirli beyaz-açık gri renkli, orta kalın tabakalı, yer yer tabakasız, bazı düzeyleri bol fosilli, bol çatlaklı ve makro fosil kavkılıdır. Birimin üst düzeylerinde çört yumruları izlenmektedir. Kireçtaşları karbonat düzlüğü mikro fasiyes ortamı ile açık platform mikro fasiyes ortamında çökelmiştir. Birimin yaşını Terlemez ve diğerleri [2] tarafindan Orta (Üst Lütesiyen)-Üst (Priyaboniyen) Eosen olarak belirlemiştir.

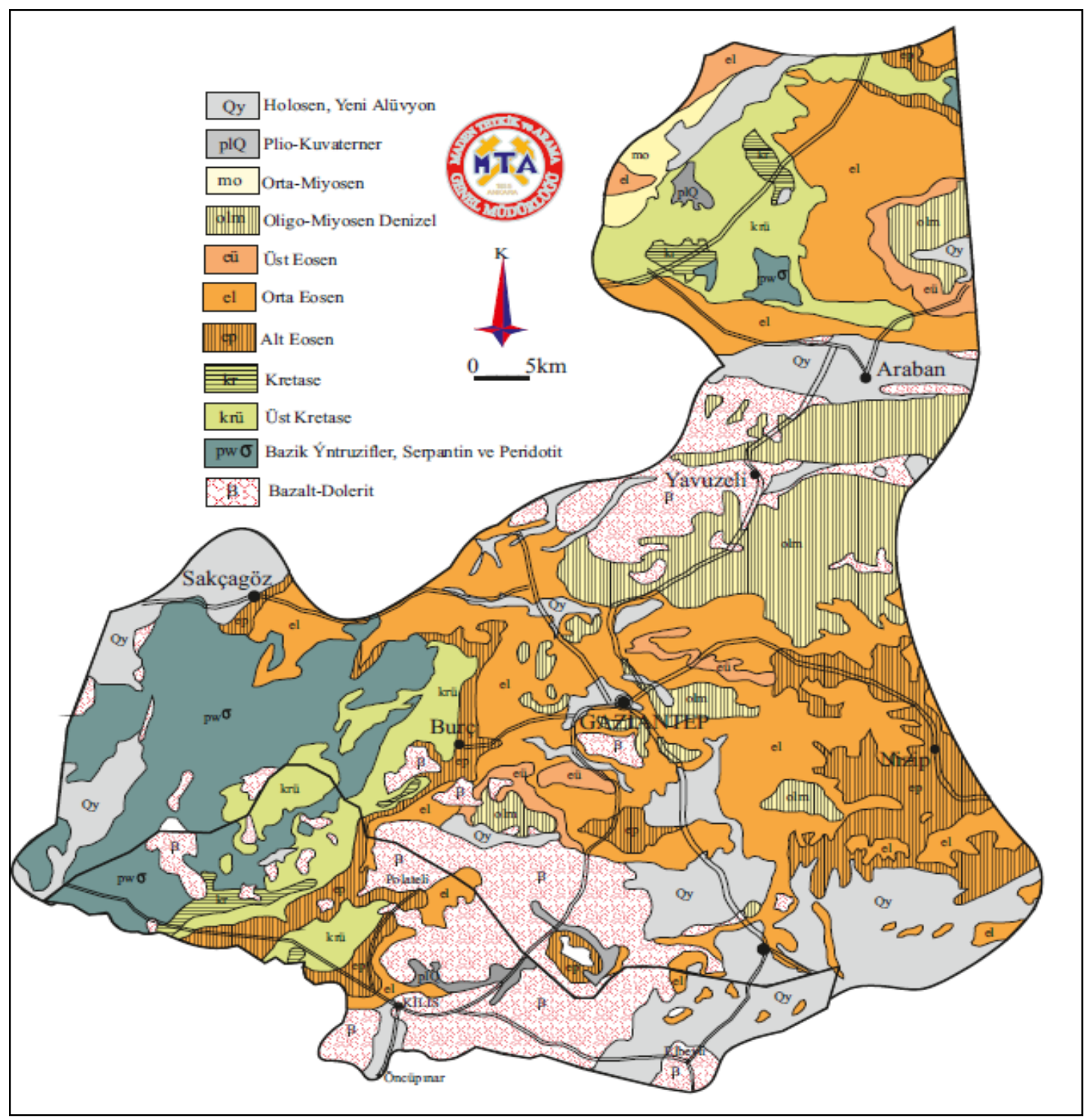

Şekil 3. Jeoloji haritası [3] 
Çalışma sahasının batısında gözlenen birim; Çakıl taşı, kumtaşı, kil taşı ve çamurdan oluşan bu birimin adlandırılması ve tanımlaması Terlemez ve diğ. tarafından yapılmıştır. Birim altta çakıl taşı ile başlar. Çakıltaşları gri-açık gri renkli, tabakasız olup, kireçtaşı, ofiyolit ve radyolarit çakılları, gevşek ve egemen olarak karbonat çimento ile tutturulmuştur. Çakıltaşları üste doğru kumtaşlarına geçer. Kumtaşları gri sarı renkli, ince-orta çapraz tabakall, derecelenmelidir. Kumtaşları üste sarı renkli kil taşı ile kırmızı renkli çamur taşlarına geçer. Birimi oluşturan kaya türleri genellikle akarsu, çok az bölümü ise göl çökelleri özelliğindedir. Birimin yaşı stratigrafik konumuna dayandırılarak Pliyosen olarak kabul edilmektedir.

\section{METOD}

\subsection{Patlatma Tasarımı}

Açık ocak işletmeciliğinde, birbirini izleyen delme-patlatma, kazı-yükleme, nakliye, kır (özellikle birincil kırma) ve/veya tumba gibi faaliyetlerin tümünü birden dikkate alır kaydıyla, ekonomik ve emniyetli bir patlatmanın gerçekleşmesi, ancak güvenilir bir patlatma tasarım ile mümkün olabilmektedir. DelmePatlatma, kaya kütlesini kontrollü bir şekilde parçalayarak ana kütleden ayırma işlemidir. $\mathrm{Bu}$ nedenle delme patlatma işi cevher hazırlama tesisi için büyük miktarda iyi parçalanmış kaya kütlesi ve geride kalan şevde, şev stabilitesini bozmayacak bir delik geometrisi ile dizayn edilmelidir [4]. Yani iyi parçalanmış, kolay yüklenebilir gevşeklikte bir yığın elde etmek ve bu işlem sırasında çalışanlara, makinalara ve çevreye zarar vermeyecek veya zora kaçınılmazsa en az zararı verecek bir patlatma dizaynının yapılması gerekir. Ayrıca patlatma sonrası oluşan yığın da istenilen parça boyut dağılımına sahip olmalıdır. $\mathrm{Bu}$ ise bazı etkenlere bağlıdır. Bunlar;

\subsubsection{Doğal Faktörler}

Çalışma sahasının jeolojisi, malzemenin sertliği, yapısal süreksizlikler kayanın patlatılabilirliği kayanın patlamaya karşı direnci hava durumu gibi parametreler patlatma sirasinda kontrol edilemezler. Bundan dolayı bu özelliklerin patlatma öncesinde belirlenerek patlatma tasarımında değişebilen parametreler bu özelliklere göre dizayn edilmelidir.

\subsubsection{Kontrol Edilebilir Faktörler}

Patlatmada; dilim kalınlığı (B), delikler Arası Mesafe (S) basamak (ayna) yüksekliği (L) ve delik boyu $(\mathrm{H})$, sıkılama boyu $\left(\mathrm{h}_{\mathrm{o}}\right)$ ve malzemesi, delik eğimi, delik taban (tırnak) payı (U), çapı (d), yeri, şarj miktarı ve dağılımı, yemleme, ateşleme sırası, yönü ve gecikme süreleri, atım grubu şekli ve boyutu kontrol edilebilir parametrelerdir ve çalışma sahası ile kayaç özellikleri baz alınarak uygun olan seçim yapılmalıdır.

\subsection{Görüntü İşleme Yöntemi ile Parça Boyut Analizi}

Görüntü işleme yöntemi ile parça boyut analizi yapan pek çok program mevcuttur. Bunlardan başlıcaları Split Desktop, Wipfrag, Fragscan olarak sıralanmaktadır. $\mathrm{Bu}$ programların algoritmaların geliştirilmesi ile özellikle madencilik çalışmalarında bu tür programların kullanımını yaygın hale getirmiştir. Görüntü işleme yöntemi ile yapılan parça boyut dağılımının normal elek analizine kıyasla kayda değer ölçüde avantajlara sahiptir. Bunlardan en önemlisi pratik olması ve zaman kaybını engellemesidir. Görüntü işleme yöntemi, patlatma işleminden sonra oluşan yı ğının miktarı göz önünde bulundurulursa çok kısa zamanda en hızlı sonucu veren yöntem görüntü işleme yöntemi ile parça boyut analizidir. Üretim aksamasına sebep olmamaktadır. Daha ucuz bir yöntemdir ve ayrıca maliyet açısından daha uygundur. Bu çalışmada Maerz ve arkadaşları [5] tarafindan kurulan WipWare Inc. Şirketi bünyesinde geliştirdikleri Çukurova Üniversitesi Maden Mühendisliği Bölümü envanterlerinde mevcut olan WipFrag programını kullanılmıştır.

\subsubsection{WipJoint Yazılımı ile Patlatma Öncesi Blok Analizi}

Patlatma öncesi kaya kütlesinin sahip olduğu süreksizlik durumu patlatmanın verimi, güvenliği 
Gaziantep-Şehit Kamil-Karpuzkaya Bölgesi Kalker Işsletmesinin Patlatma Parametrelerinin İncelenmesi ve Patlatma Sonrası Parça Boyut Dağılımının Belirlenmesi

ve patlatma tasarımı açısından büyük önem taşımaktadır. $\mathrm{Bu}$ yüzden patlatma öncesi patlatma aynasındaki kaya kütlelerinin süreksizlik durumu, çatlak-kırık sistemi gibi jeolojik özelliklerinin tespit edilmesi gerekmektedir. Özellikle ayna genişliği yüksek olan patlatmalarda bu çalışmalar klasik yöntemler ile çok fazla zaman ve emek gerektirmektedir.

Görüntü işleme yöntemleri ile yapılan blok analizleri bize daha hızlı sonuçlar verebilmektedir. $\mathrm{Bu}$ çalışmada patlatma öncesi blok analizi WipJoint yazılımı aracılığı ile yapılacaktır.

Patlatma öncesinde alınan ölçekli fotoğraf bize patlatılacak yüzeyin yerinde blok boyutunu verecek ve patlatma sonrası oluşacak yığın boyutu ile kıyaslandığında patlatma verimliliği hakkında da bilgi vermiş olacaktır.

WipJoint yazılımının algoritması WipFrag programından farklıdır. WipJoint programı içerisinde yapılan işlem aşamaları [6];

1. Fotoğraflanacak ayna yüzeyinin önceden incelenmelidir.

2. Gerekli ölçek ayna yüzeyine konulmalıdır.

3. Ayna yüzeyini tam olarak kapsayan yeterli çözünürlüğe sahip fotoğraflar alınmalıdır.

4. Ölçekli fotoğraf bilgisayara aktarılmalıdır ve yazılımın içerisinde açılmalıdır.

5. Yazılım kullanılarak öncelikle görüntünün içerisindeki ölçek boyutlandırılmaktadır.

6. Daha sonra kenar belirleme ve bu kenarlar ile poligon yaratma işlemi gerçekleşmektedir.

7. Program içerisinde blokları ortaya koyan bir çatlak ağı oluşturur.

8. Kullanıcı isterse bloklarda mevcut kusur var ise elle düzeltmeler yapabilir.

9. Analiz butonu kullanılarak sonuçlar grafiksel ve istatistiksel olarak gösterilebilir.

\subsubsection{WipFrag ile Patlatma Sonrası Parça Boyut Analizi}

WipFrag ile ölçeklenmiş fotoğraflar, videolar ve dijital dosyalar ile çalışabilmektedir. Görüntü programa yüklendikten sonra otomatik olarak bir algoritma yolu ile parça sınırlarını belirlemekte ve bir parça boyut ağı oluşturmaktadır [6]. WipFrag yazılımında işlem aşamaları;

1. Oluşan yı̆̆ın eğimli ise iki ölçekli, eğim yok ise tek ölçek yerleștirilmelidir.

2. Gerekli ölçek yerleştirildikten sonra yeterli çözünürlüğe sahip yığını tam olarak analiz edebilecek sayıda fotoğraf alınmalıdır.

3. Ölçekli fotoğraf bilgisayara aktarılmalı ve yazılım içerisinde açılmalıdır.

4. Program içerisinde öncelikle görüntü içerisindeki ölçek boyutlandırılmalıdır.

5. Program otomatik olarak bir algoritma ile sinırlar belirlemektedir (Şekil 4).

6. Belirlenen sinırlarda düzeltme gerekecek bir sorun var ise kullanıcı tarafindan tüm düzeltmeler yapılmaktadır.

7. Program 2 boyutlu olarak oluşturduğu parça ağını 3 boyuta dönüştürmektedir ve analiz butonu kullanılarak sonuçlar grafiksel ve istatistiksel olarak gösterilmektedir.

8. Yı̆̆ını temsil edecek fotoğraf sayısı birden fazla ise hepsi tek tek yukarıdaki aşamalardan geçirilerek analiz edilmeli ve bu analiz sonuçları program içerisinde çoklu görüntü analizi kullanılarak tüm analizler birleştirilebilmektedir.

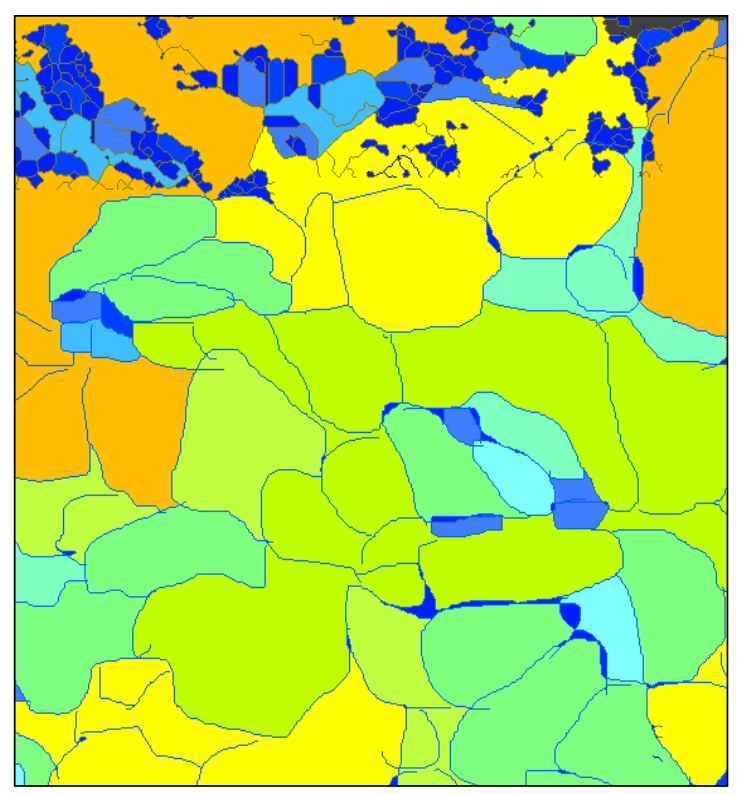

Şekil 4. Programda oluşturulan yüzeyler 


\section{ARAŞTIRMA BULGULARI}

Çalışma sahasında en uygun olan patlatma parametresi belirlenmiş ve patlatma işleminden önce patlatma öncesi ve patlatma sonrası ölçekli fotoğraflar alınmış ve bu fotoğraflar üzerinden patlatma öncesi blok analizi ve patlatma sonrası parça boyut analizi yapılmıştır.

\section{1. Çalışma Sahası Patlatma Tasarım Parametreleri}

Madencilikte yapılan patlatma çalışmalarında patlatmanın verimli olabilmesi için sahanın süreksizlik, çatlak kırık sistemi, kayaç özellikleri çok iyi belirlenmelidir. $\mathrm{Bu}$ özelliklerin iyi belirlenmemesi yapılan patlatma çalışmasının maliyetini artırmakla kalmayıp ayrıca iş sağlığı ve güvenliği açısından da pek çok risk teşkil edebilmektedir. Bundan dolayı patlatma çalışmalarının çok iyi bir şekilde planlanması gerekmektedir. İyi bir patlatma tasarımı yapabilmek için öncelikle çalışma sahasında ön inceleme yapılarak kayaç ve saha özelliklerine uygun olacağı düşünülen patlatma tasarım parametreleri örnekleri belirlenmiştir. Belirlenen tasarım parametreleri örnekleri sahada yapılan atımlarda denenmiş ve en uygun olan patern seçilmiştir. Pek çok atım izlenerek seçilen paternin uygun olup olmadığ1 incelenmiştir. Bu izlemeler sonucunda en uygun patlatma parametreleri belirlenmiştir. Saha için en uygun patlatma parametreleri Çizelge 1'de verilmiştir.

Saha genellikle masif yapıda kireçtaşı oluşumlarından meydana geldiği için ve genel olarak sahanın içerisinde çok fazla heterojen dağılım gözlenmediği için patlatma parametrelerinin saha içerisinde farklılık gerektirmesine de gerek duyulmadığ 1 gözlenmiştir. Yani aynı paternin sahanın tüm aynalarında ekonomik ve emniyetli olarak kullanılabilecektir.

\subsection{WipJoint ile Blok Boyutu Analizi}

Patlatma öncesinde blok analizi yapmak için patlatma yapılacak bölgenin ölçekli fotoğrafi alınmıştır. Programa aktarılan resim içerisindeki ölçek boyutlandırılmıştır ve program kendi içerisinde kenarlar belirleyerek bloklar oluşturmuştur. Oluşan bloklar üzerindeki hatalar düzeltilmiştir. Blok analizinde kullanılan görüntü Şekil 5'de, analiz sonrası blok boyut dağılımı ise Şekil 6'da verilmektedir.

WipJoint ile yapılan analizde patlatma öncesi maksimum blok boyutu $56,869 \mathrm{~cm}$ ve minimum blok boyutu ise $0,313 \mathrm{~cm}$ olarak bulunmuştur. Ayrica ortalama blok boyutu ise 2,548 cm olduğu belirlenerek blok dağılımı program tarafindan grafik olarak gösterilmektedir

Çizelge 1. Taş ocağında gözlemlenen patlatmanın tasarım parametreleri

\begin{tabular}{|l|c|}
\hline Delik Düzeni & Şeş Beş \\
\hline Delik Sayısı & 50 Adet \\
\hline Delik Çapı & $88,9 \mathrm{~mm}$ \\
\hline Delikler Arası Mesafe & $3 \mathrm{~m}$ \\
\hline Dilim Kalınlığı & $5 \mathrm{~m}$ \\
\hline Basamak Yüksekliği & $13 \mathrm{~m}$ \\
\hline Şarj Miktarı (1 Delik) & $56,99 \mathrm{~kg}$ \\
\hline Delik Taban Payı & $1 \mathrm{~m}$ \\
\hline Delik Boyu & $13+1=14 \mathrm{~m}$ \\
\hline Delik Eğimi & $75^{\circ}$ \\
\hline Basamak Eğimi & $80^{\circ}$ \\
\hline Su Durumu & Susuz \\
\hline Patlayıcı Madde & ANFO \\
\hline Yemleme & Jelatinit Dinamit \\
\hline Kapsül & Elektrikli \\
\hline
\end{tabular}

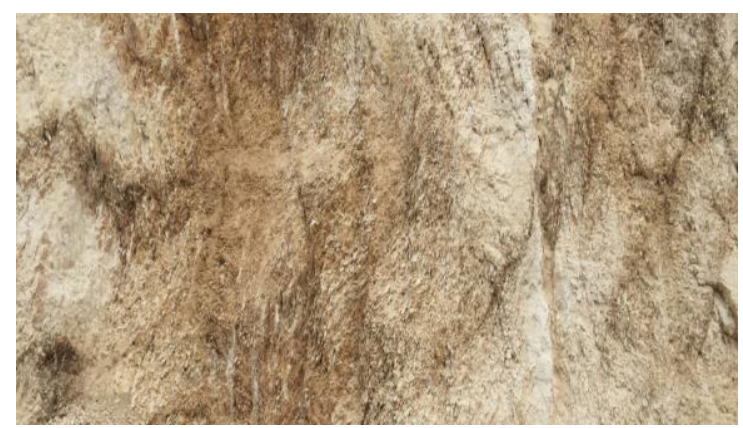

Şekil 5. Patlatma yapılacak bölgenin görüntüsü 
Gaziantep-Şehit Kamil-Karpuzkaya Bölgesi Kalker Işsletmesinin Patlatma Parametrelerinin İncelenmesi ve Patlatma Sonrası Parça Boyut Dağılımının Belirlenmesi

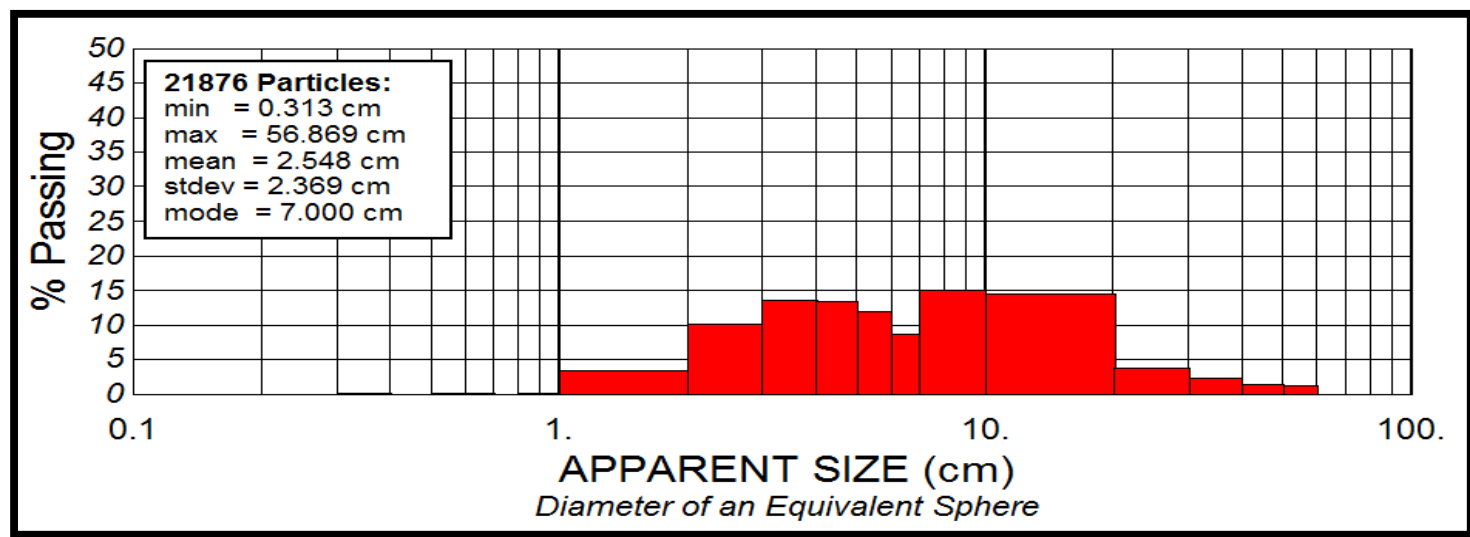

Şekil 6. Patlatma öncesi blok boyut dağılım grafiği

\subsection{WipFrag ile Patlatma Sonrası Parça Boyut Analizi}

Patlatma sonrası sahadan patlatma yığınını tam temsil edecek şekilde pek çok ölçekli fotoğraf alınarak bu fotoğraflar teker teker parça boyut analizine tabi tutulmuş ve daha sonra program yardımı ile bu grafikler birleştirilerek tek bir grafik elde edilmiştir. Böylelikle patlatma sonrası parça boyut dağılımı tam olarak yığını temsil etmiş bulunmaktadır. Şekil 6'da parça boyut analizinde kullanılan görüntülerden biri ve Şekil 7'de ise yığının parça boyut dağılımı görülmektedir. WipFrag sonucu elde edilen yığının yüzdesel dağılım oranları ise Çizelge 2'de görülmektedir.

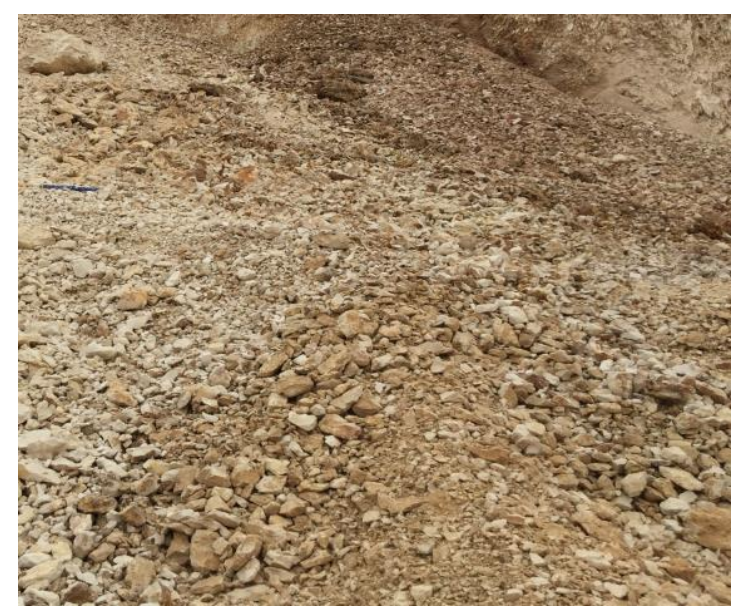

Şekil 6. Parça-boyut analizinde kullanılan görüntü örneği
Çizelge 2. WipFrag ile yığının yüzdesel dağılımı

\begin{tabular}{|c|c|}
\hline Boyut $(\mathrm{cm})$ & Geçen $\%$ \\
\hline 50 & 100 \\
\hline 40 & 98,12 \\
\hline 30 & 94,14 \\
\hline 20 & 86,12 \\
\hline 10 & 59,86 \\
\hline 7 & 46,46 \\
\hline 6 & 40,27 \\
\hline 5 & 34,10 \\
\hline 4 & 26,03 \\
\hline 3 & 17,71 \\
\hline 2 & 8,59 \\
\hline 1 & 1,70 \\
\hline 0,9 & 1,32 \\
\hline 0,8 & 1,02 \\
\hline 0,1 & 0,73 \\
\hline 0,6 & 0,49 \\
\hline 0,5 & 0,36 \\
\hline 0,4 & 0,25 \\
\hline 0,3 & 0,10 \\
\hline
\end{tabular}

Parça boyut analizi için patlatma aynasını temsil etmesi açısından yığından alınan ölçekli fotoğrafların tek tek analizi yapılmıştır. $\mathrm{Bu}$ analizler programın birleştirme özelliği yardımıyla birleştirilmiş ve patlatma alanında oluşan yığının tam olarak temsil edilmesi sağlanmıştır. Analiz sonuçlarının birleştirilmesi sonucu tam 13205 tane parça analiz edilerek bu parçaların boyutunu 
belirlemiştir. Sonuçta oluşturulan parça boyut dağ 1 lımında maksimum tane boyutunun $44,710 \mathrm{~cm}$ ve minimum tane boyutunun ise $0,221 \mathrm{~cm}$ olduğu belirlenmiştir. Ayrıca, D10, D25, D50 ve D90 değerleride belirlenmiştir.

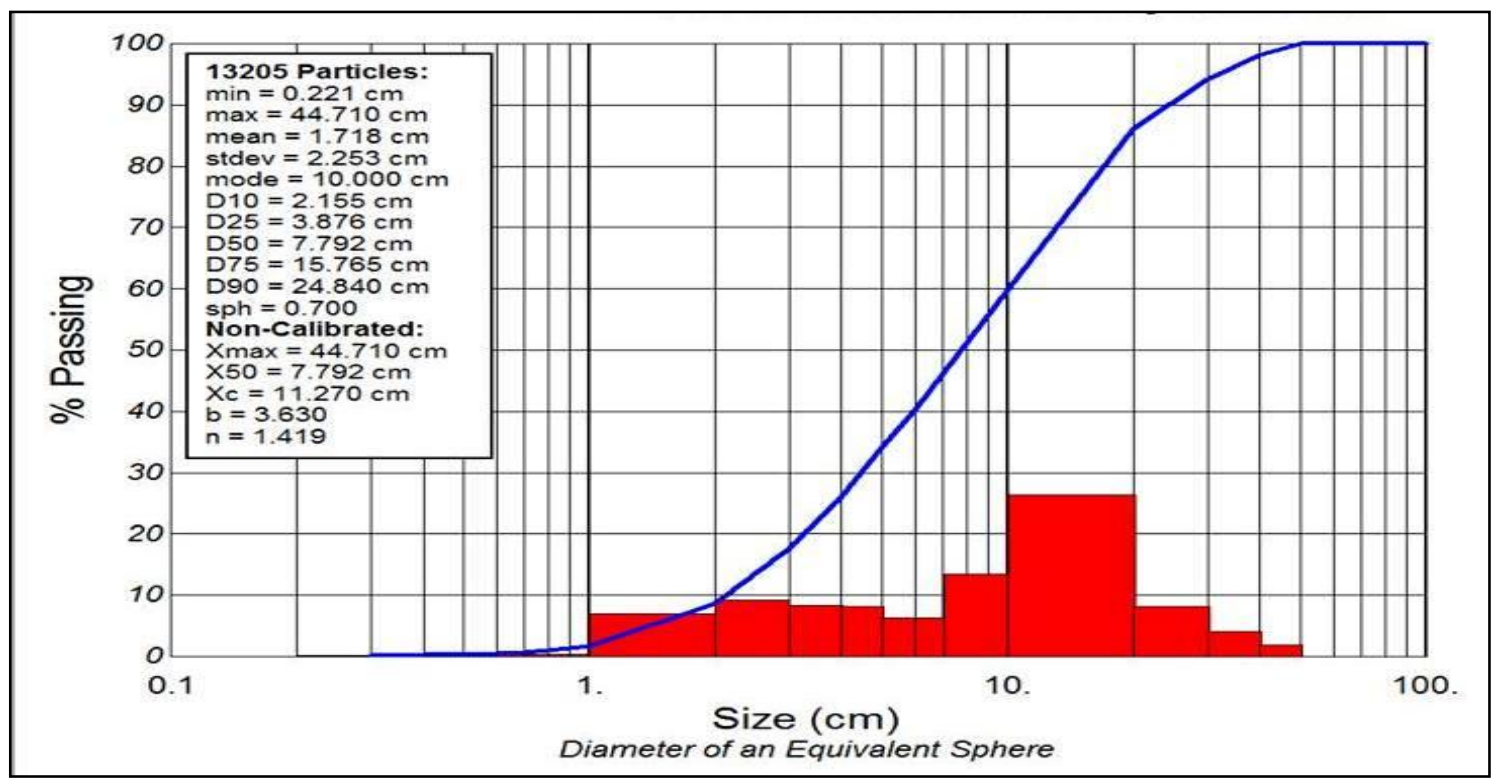

Şekil 7. Yığının parça-boyut dağılımı

\section{SONUÇLAR}

$\mathrm{Bu}$ çalışma da öncelikli olarak taş ocağında gerçekleştirilen patlatma işlemleri sonucunda istenilen parça boyutunun elde edilip edilmediği incelenmiştir. Yapılan çalışmada birçok patlatma tasarım parametresi denenmiş ve bu tasarım parametrelerinden en uygun patlatma tasarım parametresinin kullanılmasıyla patlatma işlemi gerçekleştirilmiştir.

Patlatma verimini değerlendirmek amacıyla patlatma alanından resim alınmış ve bu resimde WipJoint ile Blok Boyutu Analizi programı ile patlatma öncesi blok boyut analizi yapılmıştır. Patlatma sonrası patlatma alanında yığın resmi çekilmiş ve WipFrag ile Patlatma Sonrası Parça Boyut Analizi yapılmıştır. Patlatma sonucu elde edilen parça boyunun \%59,86's1 $10 \mathrm{~cm}$ ve altında elde edilmiş olup, bu da nakliye ve kırma açısından büyük önem taşımaktadır. Gerçekleştirilen bu analizler sonucu taş ocağında uygulanan patlatma tasarımının taş ocağı için uygun patlatma tasarım parametreleri olduğu sonucuna varılmıştır.

\section{KATKI BELIRTME}

Yazar çalışmaya sağladığı destekten dolayı ÇÜBAP (Çukurova Üniversitesi Rektörlüğü Bilimsel Araştırma Projeleri Koordinasyon Birimi, MMF2011BAP19'a teşekkür eder.

\section{KAYNAKLAR}

1. Sungurlu, O., 1974. VI Bölge Kuzey Sahalarının Jeolojisi: Türkiye İkinci Petrol Kongresi, 85-107.

2. Terlemez, H.Ç.I., Şentürk, K., Ateş, Ş., Sümengen, M. ve Oral, A., 1992. Gaziantep Dolayının ve Pazarcık-Şakçagöz-Kilis-ElbeyliOğuzeli Arasının Jeolojisi: MTA Rap. no. 9526, Ankara (yayınlanmamış). 
Gaziantep-Şehit Kamil-Karpuzkaya Bölgesi Kalker İşletmesinin Patlatma Parametrelerinin İncelenmesi ve Patlatma Sonrası Parça Boyut Dağılımının Belirlenmesi

3. M.T.A. Genel Müdürlüğü, Türkiye Jeoloji Haritaları, 2006, Ankara.

4. Kılıç, M., 2015. Patlatma Teknolojisi Ders Kitabı, Çukurova Üniversitesi Maden Mühendisliği Bölümü, Adana (yayınlanmamış).

5. Maerz, N. H., Palangio, T. C., Franklin, C. A., 1996. WipFrag image based granulometry system, Fragblast 5, Workshop on Measurement of Blast Fragmentation, Canada, Aug. 25-29, pp. 91-99.

6. Hüdaverdi, T., 2010. Parçalanmanın İyileştirilmesine Yönelik Patlatma Tasarımının Araştırılması, İTÜ Doktora Tezi, İstanbul, $187 \mathrm{~s}$. 
